\title{
PENGGUNAAN PASIR GALIAN (MATERIAL LOKAL) DI KABUPATEN MERAUKE - PAPUA SEBAGAI KOMPONEN PENYUSUN MORTAR
}

\author{
Annisa Diwya Abhayamudra, Stanley Larson, Ilham Nurhuda, Yulita Arni Priastiwi, Daud \\ Andang Pasalli \\ Departemen Teknik Sipil, Fakultas Teknik, Universitas Diponegoro \\ Email: stanleyyla@gmail.com
}

\begin{abstract}
ABSTRAK: Pembangunan infrastruktur oleh Pemerintah Indonesia dilakukan salah satunya di Kabupaten Merauke. Namun, ketersediaan material dengan mutu tinggi harus didatangkan dari luar Merauke yang mengakibatkan harganya mahal dan waktu pengiriman yang lama. Bahan konstruksi alternatif terus dicari dan dikembangkan seperti penggunaan material lokal. Tujuan dari penelitian ini untuk mengetahui pasir manakah yang terbaik sebagai bahan campuran mortar. Penelitian mortar ini menggunakan 3 (tiga) pasir dari quarry di Merauke yaitu Onggari-1, Bupul-5, dan Senayu tanpa koreksi. Perbandingan penyusun mortar antara semen dan pasir adalah 1:2 dengan FAS 0,4, dengan benda uji berupa kubus $5 \times 5 \times 5 \mathrm{~cm}$. Properties dari masing-masing pasir saat kondisi asli diuji sedangkan pengujian kuat tekan mortar dilakukan pada umur 8 hari, 14 hari dan 28 hari. Mortar juga diuji berat volume, berat jenis, dan penyerapan air nya. Hasil analisis menunjukkan bahwa Onggari-1 memenuhi sebagian besar spesifikasi properties untuk pasir beton dengan kadar lumpur kurang dari 5\%, kotoran organisnya rendah dan gradasi well-graded. Kuat tekan yang dicapai Onggari-1 merupakan kuat tekan tertinggi sebesar 38,45 MPa, diikuti Senayu sebesar 26,01 MPa dan Bupul-5 sebesar 19,44 MPa pada umur 28 hari. Pasir galian dari quarry Senayu dan Bupul-5 perlu dilakukan treatment berupa pencucian pasir dan perbaikan gradasi pasir. Secara keseluruhan, semua pasir dapat digunakan untuk pekerjaan pasangan struktur yang memikul beban besar.
\end{abstract}

Kata Kunci : Pasir Merauke, mortar, kuat tekan

\section{THE USE OF SAND (LOCAL MATERIAL) IN MERAUKE - PAPUA DISTRICT AS MORTAR COMPONENT}

\begin{abstract}
One of the infrastructure developments by the Indonesian government is in Merauke Regency. However, the availability of high-quality materials must be imported from outside, which results in high prices and long delivery times. Alternative construction materials continue to be sought and developed, such as the use of local materials. The aim of this research is to determine which sand is the best as a mortar mixture. This mortar study used 3 (three) sands from quarries in Merauke, namely Onggari-1, Bupul-5, and Senayu. The ratio of mortar constituent between cement and sand is 1:2 with FAS 0.4, with $5 \times 5 \times 5 \mathrm{~cm}$ test object. The properties of each sand were tested in original condition while the mortar compressive strength test was carried out at the age of 8 days, 14 days, and 28 days. The mortar also will be tested for volume weight, specific gravity, and water absorption. The analysis results showed Onggari-1 met most of all the properties specifications for concrete with clay particles less than 5\%, low organic impurities, and well-graded. The compressive strength achieved by Onggari-1 was the highest at 38,45 MPa, followed by Senayu at 26,01 MPa and Bupul-5 at 19,44 MPa at the age of 28 days. The highest increase in quality of each sand occurred at the age of 14 days. Sand from Senayu and Bupul-5 need maintenance in the form of washing the sand and repairing the gradation. Overall, all sands can be used as masonry work that bears heavy loads.
\end{abstract}

Keywords : Merauke Sand, mortar, compressive strength 


\section{PENDAHULUAN}

Indonesia merupakan negara kepulauan dengan sumber daya alam yang melimpah. Kekayaan sumber daya alam tersebut sebagian digunakan untuk memenuhi kebutuhan bangsa Indonesia dibidang infrastruktur. Saat ini, Indonesia sedang giat-giatnya membangun infrastruktur untuk mengejar ketinggalan dengan negara lain dalam langkah mencapai pemerataan dan pertumbuhan ekonomi.

Industri konstruksi di Indonesia saat ini banyak yang menggunakan struktur beton bertulang dan mortar untuk pembangunan gedung, jembatan, dan lain-lain. Beton bertulang memiliki kuat tekan yang tinggi dan mudah dibentuk sehingga menjadi opsi yang paling sering dipilih untuk konstruksi di Indonesia sedangkan mortar banyak digunakan sebagai elemen pendukung dari infrastruktur, seperti perekat bata, plesteran dinding, pemasangan keramik, dan lain lain. Secara umum diketahui komponen penyusun utama dari beton adalah semen, air, agregat kasar, dan agregat halus, sedangkan komponen penyusun mortar adalah semen, air, dan agregat halus.

Namun tidak semua wilayah di Indonesia memiliki potensi ketersediaan agregat yang sama, sehingga penggunaan agregat untuk pembangunan harus diperhatikan ketersediaannya di masingmasing wilayah. Wilayah dengan ketersediaan agregat yang kurang bagus harus mendatangkan material dari wilayah lain dengan biaya yang cukup mahal. Berbagai bahan konstruksi alternatif terus dicari dan dikembangkan seperti penggunaan material lokal. Pembangunan infrastruktur oleh Pemerintah Indonesia dilakukan salah satunya di Kabupaten Merauke. Secara topografi daerah selatan Papua terdiri dari dataran rendah dan landai yang banyak terdapat rawa serta lahan gambut yang kebanyakan terdiri dari tanah lempung, sehingga jarang tersedia pasir yang layak untuk material konstruksi (Yasin dkk, 2018). Pada penelitian penggunaan agregat lokal di Distrik Muting, Kabupaten Merauke, sebagai komponen penyusun beton non struktur, agregat tersebut memiliki sifatsifat yang baik sehingga dapat memenuhi sifat beton standar, namun kebutuhan semen pada beton cenderung lebih banyak jika dibandingkan dengan beton normal (Pasalli, 2012) Penelitian lain yang pernah dilakukan yaitu penggunaan agregat dari Salor, Kabupaten Merauke, sebagai komponen penyusun mortar. Dari hasil pengujian mortar didapatkan hasil yang menunjukan mortar tersebut dapat dipergunakan untuk dinding, pilar, kolom, atau bagian bangunan lain yang menahan beban. Pasir
Merauke sebagai sumber daya alam lokal dapat dimanfaatkan secara maksimal dan dapat digunakan sebagai bahan campuran mortar dan beton, namun kebutuhan berat semennya tiap satu meter kubik cenderung lebih banyak (Pasalli, 2012). Informasi mengenai kualitas material di Merauke masih sangat terbatas sedangkan permintaan material cukup tinggi sehingga material dengan mutu tinggi harus didatangkan dari luar Merauke yang mengakibatkan harganya mahal dan waktu pengiriman yang lama. Oleh karena itu diperlukan alternatif lain untuk menghemat pengeluaran, salah satunya pemerintah setempat memakai soilcement sebagai solusi dalam hal perkerasan jalan, yaitu sebagai lapisan base maupun sub base (Yasin dkk, 2018). Soilcement merupakan hasil pencampuran tanah, semen, dan air yang dengan tingkat pemadatan tertentu akan menghasilkan material dengan kekuatan, ketahanan terhadap air, dan cuaca yang baik. Soilcement juga banyak dikembangkan di lokasi yang memiliki tanah lunak seperti di Margomulyo, Surabaya sebagai soilcement column untuk memperbaiki daya dukung tanah dibawah pondasi tiang yang digunakan untuk memikul beban diatasnya (Halim dan Prawono, 2015)

Kondisi lahan di Marauke yang mayoritas berupa tanah lempung, juga menyebabkan bahan konstruksi alternatif berbasis tanah dan lumpur lebih banyak digunakan. Beton yang diproduksi dengan menggunakan tanah, semen, dan air atau yang biasa disebut Mud Concrete memiliki konsep menggabungkan kekuatan dan daya tahan beton kedalam konstruksi berbasis tanah dengan biaya rendah, minim dampak terhadap lingkungan, tanpa melupakan kekuatan konstruksi itu sendiri. Campuran ini memiliki kemampuan untuk memadatkan dirinya sendiri dan produknya akan memiliki kenyamanan termal interior yang baik (Arooz \& Halwatura, 2018). Bata lumpur atau mud bricks juga menjadi alternatif material yang berbahan dasar tanah. Bangunan dengan bata lumpur dapat menyimpan panas selama siang hari untuk pelepasan lambat di malam hari (Sheweka, 2011). Kekurangannya adalah rapuh terhadap beban gempa bumi dan lemah terhadap kembang-susut akibat air yang dapat menyebabkan keretakan (Chhaba and Singh, 2017). Evaluasi kinerja konstruksi berbasis tanah masih harus dilakukan untuk mendapatkan proporsi yang tepat, baik dengan bahan kimia tambahan maupun tidak.

Banyaknya pemanfaatan konstruksi berbasis material lokal di Kabupaten Merauke memungkinkan konstruksi dapat dilakukan tanpa mengeluarkan biaya lebih untuk mendatangkan 
material dari luar dan waktu pengiriman yang lama. Berdasarkan faktor-faktor yang telah disebutkan sebelumnya, maka penelitian dan pengembangan mengenai pasir di Merauke masih sangat diperlukan.

Tujuan dari penelitian ini untuk mengetahui sifat-sifat fisik material di Kabupaten Merauke sebagai komponen penyusun mortar yang nantinya dapat menjadi dasar perancangan campuran beton struktural maupun pertimbangan sebagai bahan perkerasan jalan di lokasi tersebut.

\section{METODE}

Penelitian tentang penggunaan pasir galian sebagai komponen penyusun mortar adalah penelitian eksperimental yang dilakukan di laboratorium. Produksi benda uji dan seluruh pengujian dilakukan di Laboratorium Bahan dan Konstruksi Universitas Diponegoro, Semarang. Penelitian ini diawali dengan pengujian properties pasir berupa kandungan lumpur, kotoran organis, analisis saringan, kadar air, berat isi, dan berat jenis kemudian dilanjutkan dengan pembuatan dan pengujian mortar antara lain kuat tekan, berat volume, berat jenis, penyerapan air, dan pola pecah. Pasir yang digunakan untuk pembuatan benda uji mortar dalam kondisi tanpa koreksi dengan maksud untuk mengetahui sifat-sifat mortar dari pasir pada kondisi sebenarnya. Semen yang digunakan adalah Portland Cement tipe I, yang diproduksi oleh PT.

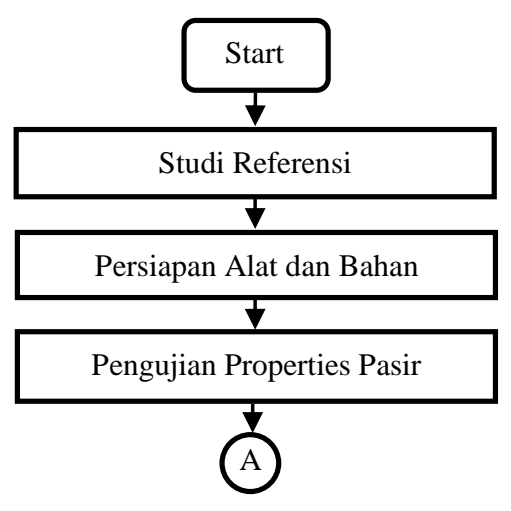

Semen Gresik dengan berat jenis semen 3,15. Sebelum diuji kuat tekan, benda uji mortar ditimbang terlebih dahulu untuk mendapatkan nilai berat volume. Pengujian kuat tekan mortar mengacu pada SNI 03-6825-2002 menggunakan Compression Testing Machine yang terhubung dengan komputer. Dari pengujian tersebut didapatkan gaya maksimum per satuan luas yang bekerja pada setiap benda uji mortar. Mortar yang telah diuji kuat tekan diamati pola pecahnya dan serpihannya diambil untuk pengujian berat jenis. Pengujian berat jenis mengacu pada ASTM UOP 766:2013 menggunakan air raksa dengan sampel serpihan mortar. Air raksa digunakan karena sifatnya yang cair namun tidak menyerap kedalam benda uji. Pengujian penyerapan air mengacu pada ASTM C1403-05 menggunakan wadah yang terisi air dan jaring-jaring untuk menjaga bagian bawah mortar tetap basah. Adapun diagram alir dalam penelitian ini dapat dilihat pada Gambar 1.

\section{Benda Uji}

Benda uji pada penelitian ini merupakan mortar dengan dimensi 50x50x50 mm. dengan komposisi 1pc : 2 ps tanpa koreksi, dengan FAS sebesar 0,4. Untuk jumlah pembuatan benda uji mortar dalam penelitian ini dilakukan seperti yang ditunjukkan pada Tabel 1.

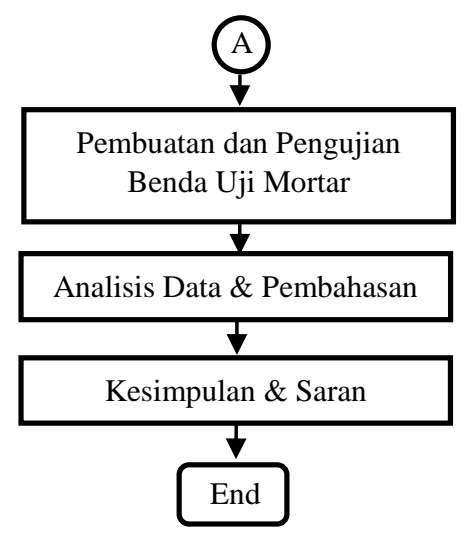

Gambar 1. Diagram Alir Penelitian

Tabel 1. Rencana Jumlah Benda Uji

\begin{tabular}{lcccc}
\hline \multicolumn{1}{c}{$\begin{array}{c}\text { Mortar } \\
\mathbf{( 5 0 x 5 0 x 5 0} \mathbf{~ m m})\end{array}$} & Onggari-1 & Bupul-5 & Senayu & \multirow{2}{*}{ Jumlah Benda Uji } \\
\cline { 2 - 4 } Kuat Tekan (8 hari) & 3 & 3 & 3 & 9 \\
Kuat Tekan (14 hari) & 3 & 3 & 3 & 9 \\
Kuat Tekan (28 hari) & 3 & 3 & 3 & 9 \\
Penyerapan Air (15 menit) & 3 & 3 & 3 & 9 \\
Penyerapan Air (24 jam) & 3 & 3 & 3 & 9 \\
& Total & & & $\mathbf{4 5}$ \\
\hline
\end{tabular}




\section{HASIL ANALISIS DAN PEMBAHASAN}

\section{Pengujian Properties Pasir}

Hasil pengujian pasir pada masing-masing quarry dapat dilihat pada Tabel 2, Tabel 3, dan Tabel 4. Tabel 1. Rekapitulasi Pengujian Properties Onggari-1

\begin{tabular}{lccc}
\hline \multicolumn{1}{c}{ Pengujian } & Hasil Uji & Spesifikasi & Kategori \\
\hline Kandungan Lumpur & $2,89 \%$ & SNI 8321:2016 $(<5 \%)$ & Memenuhi \\
Kotoran Organis & $\begin{array}{c}\text { Kuning Keemasa } \\
\text { (minyak) }\end{array}$ & $\begin{array}{c}\text { SNI 8321:2016 } \\
\text { (Jernih - Kuning Tua) }\end{array}$ & Memenuhi \\
Analisis Saringan (FM) & well-graded $(2,751)$ & ASTM C33 - 03 Pasal 6.2 $(2,3-3,1)$ & Memenuhi \\
Analisis Kadar Air & & SNI 03-6819-2002 & \\
Kondisi Asli & $3,465 \%$ & $<3 \%$ & Tidak Memenuhi \\
Kondisi SSD & $2,855 \%$ & $<3 \%$ & Memenuhi \\
Berat Isi & & ACI Education Bulletin E1-99 & \\
Kondisi Asli Gembur & 1470 & $1280-1920 \mathrm{~kg} / \mathrm{m} 3$ & Memenuhi \\
Kondisi Asli Padat & 1657 & $1280-1920 \mathrm{~kg} / \mathrm{m} 3$ & Memenuhi \\
Kondisi SSD Gembur & 1528 & $1280-1920 \mathrm{~kg} / \mathrm{m3}$ & Memenuhi \\
Kondisi SSD Padat & 1690 & $1280-1920 \mathrm{~kg} / \mathrm{m} 3$ & Memenuhi \\
Berat Jenis & & ACI Education Bulletin E1-99 & \\
Kondisi Asli & 2,47 & $2,3-2,90$ & Memenuhi \\
Kondisi SSD & 2,29 & $2,3-2,90$ & Memenuhi \\
\hline
\end{tabular}

Tabel 2. Rekapitulasi Pengujian Properties Bupul-5

\begin{tabular}{|c|c|c|c|}
\hline Pengujian & Hasil Uji & Spesifikasi & Kategori \\
\hline Kandungan Lumpur & $0,83 \%$ & SNI 8321:2016 $(<5 \%)$ & Memenuhi \\
\hline Kotoran Organis & Hitam & $\begin{array}{c}\text { SNI 8321:2016 } \\
\text { (Jernih - Kuning Tua) }\end{array}$ & Tidak Memenuhi \\
\hline Analisis Saringan (FM) & gap-graded $(3,703)$ & ASTM C33 - 03 Pasal $6.2(2,3-3,1)$ & Tidak Memenuhi \\
\hline Analisis Kadar Air & & SNI 03-6819-2002 & \\
\hline Kondisi Asli & $6,88 \%$ & $<3 \%$ & Tidak Memenuhi \\
\hline Kondisi SSD & $5,88 \%$ & $<3 \%$ & Tidak Memenuhi \\
\hline Berat Isi & & ACI Education Bulletin E1-99 & \\
\hline Kondisi Asli Gembur & 1446 & $1280-1920 \mathrm{~kg} / \mathrm{m} 3$ & Memenuhi \\
\hline Kondisi Asli Padat & 1554 & $1280-1920 \mathrm{~kg} / \mathrm{m} 3$ & Memenuhi \\
\hline Kondisi SSD Gembur & 1443 & $1280-1920 \mathrm{~kg} / \mathrm{m}^{3}$ & Memenuhi \\
\hline Kondisi SSD Padat & 1630 & $1280-1920 \mathrm{~kg} / \mathrm{m}^{3}$ & Memenuhi \\
\hline Berat Jenis & & ACI Education Bulletin E1-99 & \\
\hline Kondisi Asli & 2,37 & $2,3-2,90$ & Memenuhi \\
\hline Kondisi SSD & 2,45 & $2,3-2,90$ & Memenuhi \\
\hline
\end{tabular}


Tabel 3. Rekapitulasi Pengujian Properties Senayu

\begin{tabular}{lccc}
\hline \multicolumn{1}{c}{ Pengujian } & Hasil Uji & Spesifikasi & Kategori \\
\hline Kandungan Lumpur & $30,25 \%$ & SNI 8321:2016 $(<5 \%)$ & Tidak Memenuhi \\
Kotoran Organis & Hitam (agak coklat) & $\begin{array}{c}\text { SNI 8321:2016 } \\
\text { (Jernih - Kuning Tua) }\end{array}$ & Tidak Memenuhi \\
Analisis Saringan (FM) & gap-graded (3,704) & ASTM C33 - 03 Pasal 6.2 $(2,3-3,1)$ & Tidak Memenuhi \\
Analisis Kadar Air & & SNI 03-6819-2002 & \\
Kondisi Asli & $12,31 \%$ & $<3 \%$ & Tidak Memenuhi \\
Kondisi SSD & $3,84 \%$ & $<3 \%$ & Tidak Memenuhi \\
Berat Isi & & ACI Education Bulletin E1-99 & \\
Kondisi Asli Gembur & 1355 & $1280-1920 \mathrm{~kg} / \mathrm{m}^{3}$ & Memenuhi \\
Kondisi Asli Padat & 1919 & $1280-1920 \mathrm{~kg} / \mathrm{m}^{3}$ & Memenuhi \\
Kondisi SSD Gembur & 1547 & $1280-1920 \mathrm{~kg} / \mathrm{m}^{3}$ & Memenuhi \\
Kondisi SSD Padat & 1836 & $1280-1920 \mathrm{~kg} / \mathrm{m}^{3}$ & Memenuhi \\
Berat Jenis & & ACI Education Bulletin E1-99 & \\
Kondisi Asli & 2,53 & $2,3-2,90$ & Memenuhi \\
Kondisi SSD & 2,51 & $2,3-2,90$ & Memenuhi \\
& & & \\
\hline
\end{tabular}

\section{Kuat Tekan Mortar}

Untuk memperoleh data kuat tekan, digunakan sembilan (9) buah sampel kubus mortar yang nantinya akan diuji kuat tekannya. Pengujian kuat tekan mortar dilakukan pada saat mortar berumur 8 , 14, dan 28 hari.

Hubungan kuat tekan mortar dengan umur mortar dapat dilihat pada Gambar 2. Data kuat tekan pada Gambar 2 menunjukkan, mortar dari semua quarry mengalami peningkatan dari umur 8, 14, sampai 28 hari. Pada umur 14 hari, Onggari-1 memiliki peningkatan mutu sebesar $21,88 \%$, Senayu sebesar 6,38\% dan Bupul-5 sebesar 18,78\% terhadap umur 8 hari. Pada umur 28 hari, Onggari-1 memiliki peningkatan sebesar $6,91 \%$, Senayu sebesar $2,59 \%$, dan Bupul-5 sebesar 0,13\% terhadap umur 14 hari. Peningkatan mutu tertinggi pada masing-masing pasir terjadi pada umur 14 hari terhadap umur 8 hari.

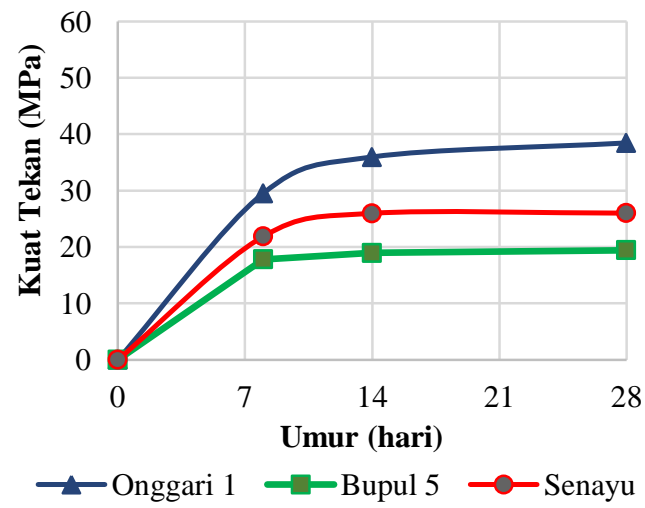

Gambar 2. Hubungan Kuat Tekan Mortar dengan Umur Mortar
Hasil kuat tekan tertinggi adalah mortar dari quarry Onggari-1 sebesar 38,45 MPa pada umur 28 hari. Dari pengujian properties pasir Onggari-1 pada kondisi SSD seluruhnya terpenuhi seperti kandungan lumpur $<5 \%$, kotoran organis yang rendah dan gradasi well-graded. Adapun kuat tekan mortar pasir quarry Senayu dan Bupul-5 yang memiliki kuat tekan 26,01 dan 19,44 MPa pada umur 28 hari. Beberapa kriteria properties pasir tersebut tidak memenuhi persyaratan yang ada seperti kandungan lumpur $>5 \%$, kotoran organis yang tinggi, dan gradasi gap-graded.

Kandungan lumpur yang tinggi menyebabkan pasir tidak terikat sempurna dengan pasta semen karena terhalang oleh lumpur pada pasir. Gradasi gap-graded memiliki stabilitas rendah karena fraksi agregat yang tidak ada atau jumlahnya kurang dari persyaratan. Selain itu, semakin banyak kotoran organis yang terkandung didalam pasir, semakin rendah kuat tekan yang dihasilkan mortar.

Selain faktor properties material diatas, pengadukan serta pemadatan saat pembuatan benda uji mortar juga menjadi faktor penting yang mempengaruhi kuat tekan mortar. Pengadukan dalam penelitian ini tidak menggunakan mesin pengaduk melainkan dengan tenaga manusia, sehingga tingkat keseragamannya lebih rendah dibanding menggunakan mesin. Pengadukan tenaga manusia juga membutuhkan waktu yang lebih lama daripada menggunakan mesin, yang memungkinkan campuran mengeras dan kurangnya air akibat terpakai proses hidrasi semen. Dapat dilihat dari 
kuat tekan mortar dari tiga sampel masih terdapat salah satu sampel dengan kuat tekan berbeda jauh dari dua sampel yang lainnya. Pemadatan pada campuran mortar Bupul-5 kurang sempurna disebabkan oleh takaran air yang sama pada ketiga quarry namun campuran mortar Bupul-5 lebih kering dari quarry yang lain dan lebih sulit dipadatkan, sehingga bagian permukaan bawah mortar pada saat dicor mengalami keropos. Mortar yang keropos kekuatannya akan berkurang. Mortar Senayu dan Onggari-1 memiliki permukaan mortar halus sempurna yang berdampak pada kuat tekannya yang lebih optimal.

Kuat tekan mortar merupakan komponen utama dalam menentukan kualitas mortar. Berdasarkan hasil penelitian ini, yang dominan menentukan kuat tekan mortar adalah kandungan lumpur, kotoran organis, gradasi pasir, dan pemadatan campuran.

\section{Hubungan Berat Jenis Pasir, Berat Volume Mortar, dan Berat Jenis Mortar}

Berdasarkan hasil pengujian berat jenis pasir, berat volume mortar, dan berat jenis mortar, dapat diringkas menjadi Tabel 5.

Tabel 5. Rekapitulasi Berat Jenis Pasir, Berat Volume Mortar, dan Berat Jenis Mortar

\begin{tabular}{lccc}
\hline Quarry & $\begin{array}{c}\text { Berat Jenis } \\
\text { Pasir Kondisi } \\
\text { SSD }\end{array}$ & $\begin{array}{c}\text { Berat Volume } \\
\text { Mortar } \\
\text { (gram/cm }\end{array}$ & $\begin{array}{c}\text { Berat } \\
\text { Jenis } \\
\text { Mortar }\end{array}$ \\
\hline Onggari-1 & 2,29 & 2,25 & 1,89 \\
Bupul-5 & 2,45 & 2,24 & 1,88 \\
Senayu & 2,51 & 2,24 & 2,00 \\
\hline
\end{tabular}

Berdasarkan Tabel 5, berat jenis pasir Senayu dan Bupul-5 lebih besar dibanding Onggari-1 maka seharusnya berat jenis mortar yang dihasilkan Senayu dan Bupul-5 lebih besar dibanding Onggari1. Namun pada pengujian berat volume mortar, Onggari-1 justru memiliki berat volume mortar yang lebih besar. Hal ini bisa diakibatkan karena adanya pori/kekosongan berisi lumpur halus yang larut saat terkena air saat pembuatan mortar pada pasir Senayu dan Bupul-5.

Pada berat jenis mortar, Senayu memiliki berat jenis mortar paling tinggi dibanding Onggari-1 dan Bupul-5. Namun Bupul-5 memiliki berat jenis mortar yang lebih rendah dibanding Onggari-1. Hal ini bisa diakibatkan pada saat pengujian, sampel yang dipilih kurang mewakili, dimana kondisi sampel hanya terdiri dari fragmen yang berisi semen atau sampel hanya terdiri dari fragmen pasir sehingga menghasilkan nilai berat jenis yang tidak merata.
Maka, untuk berat jenis mortar dipilih yang menggunakan perbandingan berat dengan volume mortar daripada yang menggunakan raksa karena lebih mewakili keseluruhan mortar dan mendekati dengan berat jenis pasir masing-masing quarry.

\section{Penyerapan Air Mortar}

Benda uji yang digunakan pada pengujian dengan lama perendaman 15 menit dan 24 jam berbeda, tetapi masih dalam adukan yang sama. Grafik penyerapan air pada mortar dapat dilihat pada Gambar 3.

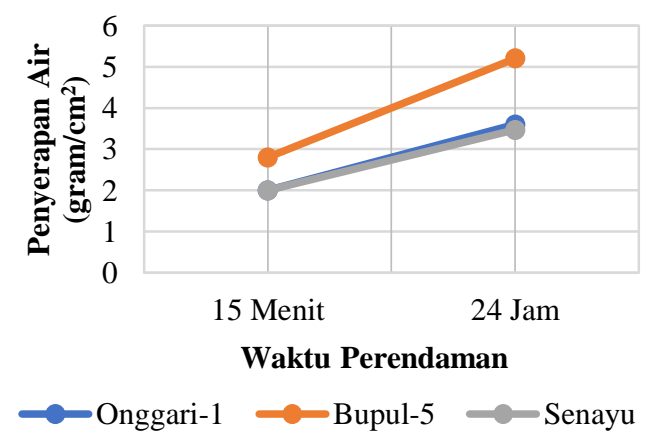

Gambar 3. Grafik Penyerapan Air Pada Mortar

Secara keseluruhan, nilai penyerapan air yang didapat pada mortar cenderung kecil. Jika dibandingkan dengan kuat tekan masing-masing, didapatkan quarry Bupul-5 memiliki kuat tekan paling rendah dengan penyerapan air tertinggi dibandingkan dengan Onggari-1 dan Senayu. Penyerapan air Bupul-5 yang tinggi mengurangi kuat tekan mortar karena kehilangan ikatan adhesinya. Nilai penyerapan air Senayu dan Onggari-1 sama pada waktu 15 menit perendaman, sedangkan pada waktu 24 jam perendaman hanya berbeda $0,13 \mathrm{gram} / \mathrm{cm}^{2}$. Ikatan adhesi pada Senayu dan Onggari-1 lebih terjaga dibanding Bupul-5.

\section{Pola Pecah Mortar}

Hasil pengamatan pada pengujian mortar diperoleh pola pecah pada mortar sesuai dengan kaidah mekanika dimana dalam keadaan mortar dikekang oleh dua (2) buah pelat, mortar mengalami perilaku pecah tekan. Gambar 4 menunjukkan mortar dengan pola pecah tekan.

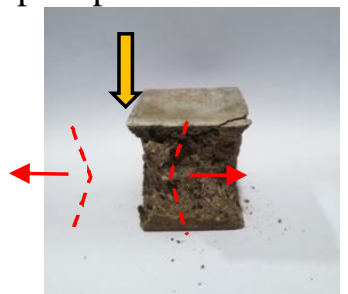

Gambar 4. Mortar Dengan Pola Pecah Tekan 
Namun, terdapat juga pola pecah pada mortar berbentuk kolumnar. Tipe kegagalan kolumnar terdefinisi sebagai tipe kegagalan yang sering terbentuk pada pengujian mortar, dimana terdapat pola pecah memanjang saling berpotongan dan retak arah lateral berkembang. Hal ini dapat disebabkan karena campuran benda uji tidak homogen dan pemadatan yang tidak merata.

Tabel 6. Pola Pecah Tiap Benda Uji

\begin{tabular}{ccc}
\hline Quarry & Sampel & Pola Pecah \\
\hline \multirow{2}{*}{ Onggari-1 } & 1 & Tekan \\
& 2 & Tekan \\
& 3 & Tekan \\
Bupul-5 & 1 & Kolumnar \\
& 2 & Kolumnar \\
& 3 & Kolumnar \\
& 1 & Kolumnar \\
Senayu & 2 & Kolumnar \\
& 3 & Kolumnar \\
\hline
\end{tabular}

\section{SIMPULAN}

Berdasarkan penelitian yang dilakukan mengenai penggunaan pasir galian sebagai komponen penyusun mortar dapat diperoleh beberapa kesimpulan sebagai berikut:

a. Pada pengujian properties masing-masing pasir, Onggari-1 memiliki kadar lumpur 2,89\% dengan gradasi well-graded, Senayu memiliki kadar lumpur 30,25\% dengan gradasi gap-graded, dan Bupul-5 memiliki kadar lumpur 0,83\% dengan gradasi gap-graded. Hasil pengujian properties masing-masing quarry menunjukkan pengaruhnya pada kuat tekan mortar. Hal ini ditunjukkan dari perolehan kuat tekan mortar tertinggi pada umur 28 hari adalah Onggari-1 sebesar 38,45 MPa diikuti Senayu sebesar 26,01 MPa dan Bupul-5 sebesar 19,44 MPa.

b. Kuat tekan mortar pada masing-masing pasir yang digunakan menunjukkan peningkatan dari umur 8 hari, 14 hari sampai umur 28 hari. Pada umur 14 hari, Onggari-1 memiliki peningkatan mutu sebesar 21,88\%, Senayu sebesar 6,38\% dan Bupul-5 sebesar 18,78\%. Pada umur 28 hari, Onggari-1 memiliki peningkatan sebesar 6,91\%, Senayu sebesar 2,59\%, dan Bupul-5 sebesar $0,13 \%$ terhadap umur 14 hari. Peningkatan mutu mortar tertinggi pada masing-masing pasir terjadi pada umur 14 hari.

c. Pada penelitian ini, berat jenis pasir tidak berbanding lurus dengan berat jenis mortar yang dihasilkan. Hal ini dapat disebabkan karena adanya pori/kekosongan pada mortar dan sampel yang dipilih kurang mewakili. Berat jenis mortar didapat dari perbandingan berat dengan volume mortar. Mortar Onggari-1 memiliki berat volume sebesar $2,25 \mathrm{gram} / \mathrm{cm}^{3}$, Senayu dan Bupul-5 sebesar 2,24 gram $/ \mathrm{cm}^{3}$.

d. Besarnya penyerapan air mortar berpengaruh terhadap kuat tekannya. Mortar dengan kuat tekan terendah adalah Bupul-5 yang memiliki penyerapan air tertinggi sebesar $2,8 \mathrm{gram} / \mathrm{cm}^{2}$ dengan lama perendaman 15 menit dan 5,2 gram $/ \mathrm{cm}^{2}$ dengan lama perendaman $24 \mathrm{jam}$.

e. Dari hasil pengamatan, pola pecah mortar yang terjadi sesuai dengan kaidah mekanika dimana dalam keadaan mortar dikekang oleh 2 buah pelat, mortar mengalami perilaku pecah tekan. Namun beberapa benda uji mengalami pecah kolumnar. Hal ini dapat disebabkan karena campuran benda uji tidak homogen dan pemadatan yang tidak merata.

f. Agregat dari quarry Onggari-1 pada kondisi tanpa koreksi dapat digunakan untuk campuran beton karena memenuhi spesifikasi. Quarry Senayu diperlukan treatment berupa pencucian dan perbaikan gradasi pasir sedangkan quarry Bupul-5 perlu perbaikan gradasi pasir sampai memenuhi spesifikasi agar dapat digunakan sebagai campuran beton.

\section{DAFTAR PUSTAKA}

ACI Standard. 1999. Aggregrates for Concrete (ACI E1-99). Farmington Hills, USA: American Concrete Institute.

Arooz, \& Halwatura. 2018. Mud-Concrete Block (MCB): Mix Design \& Durability Characteristics. Case Studies in Construction Materials, 9,

ASTM Standard. 2003. Standard Specification for Concrete Aggregates (ASTM C33-03). West Conshohocken, USA: ASTM International.

ASTM Standard. 2013. Piece Density by Mercury Displacement (ASTM UOP766-13). West Conshohocken, USA: ASTM International.

ASTM Standard. 2015. Standard Test Method for Rate of Water Absorption of Masonry Mortars (ASTM C1403). West Conshohocken, USA: ASTM International.

Badan Standardisasi Nasional. 2002. Metode Pengujian Kekuatan Tekan Mortar Semen Portland Untuk Pekerjaan Sipil (SNI 036825-2002). Jakarta, Indonesia: Departemen Pekerjaan Umum.

Badan Standardisasi Nasional. 2002. Spesifikasi Agregat Halus Untuk Campuran Perkerasan Beraspal (SNI 03-6819-2002). Jakarta, Indonesia: Departemen Pekerjaan Umum. 
Badan Standardisasi Nasional. 2016. Spesifikasi agregat beton (ASTM C33/C33M - 13, IDT) (SNI 8321:2016). Jakarta, Indonesia: Departemen Pekerjaan Umum.

Chhaba, S., dan Singh, C. 2017. Performance of Mud Brick in Building Construction System. International Journal of Engineering Technology and Computer Research, 4, 128-132.

Halim, A., dan Prawono, S. 2015. Pengaruh Campuran Semen Dalam Pembuatan Soil Cement Column Pada Tanah MargomulyoSurabaya. Jurnal Dimensi Pratama Teknik Sipil, 4, 1-7.

Pasalli, D. A. 2012. Sifat-Sifat Mortar Dari Pasir Merauke di Kabupaten Merauke-Papua. Jurnal Ilmiah Mustek Anim Ha, Vol 1, No 1.

Sheweka, S. 2011. Using Mud Bricks as a Temporary Solution for Gaza Reconstruction. Energy Procedia, 6, 236240.

Yasin, B., Said, L. B, Maryam-H, St. 2018. Analisis Ketebalan Dan Komposisi Pada Konstruksi Soil Semen (Studi Kasus: PT Elevasi Sagarmatha - Merauke). 1, 81-87. Retrieved from

http://mtsumi.ac.id/magistertekniksipil.html 